\title{
WYRÓŻNICOWANIE SIĘ RELIGII
}

Niklas Luhmann

\section{/// 4.}

W cywilizacjach starożytnych religia miała za zadanie przede wszystkim wytwarzać schemat moralności. Można uznać to za wystarczający opis jej funkcji w tym okresie. Kosmologiczne ustanowienie moralności wymagało semantycznych warunków ramowych. Można jednocześnie wywnioskować, że religia opierała się na powszechnym interesie społecznym, a mianowicie na interesie uzasadnienia różnicy między dobrem a złem, z którą każdy miał do czynienia w codziennym życiu - albo samodzielnie wybierając między tymi dwiema możliwościami, albo stojąc w obliczu problemu, jak pozostać dobrym, jeśli inni źle mnie traktują.

W powszechnym micie emanacji, wyjaśniającym, jak z jedności powstała różnica, a nawet opozycja, powstawanie moralności jest jedynie przypadkiem powstawania porządku. Podobnie objaśnia się powstanie czasu, ruchu, prawdy oraz błędu. W tym kontekście można odnaleźć takie opowieści, które w szczególny sposób służą uzasadnieniu rozróżnienia, praktykowanemu następnie jako moralność i nieuchronnie wystawiającemu ludzi na konfrontacje ze złem. Jeden z mitów powiela ten problem, rozdzielając powstanie różnicy na aniołów i ludzi, prowadzącej do pytania, jak mają się zachowywać aniołowie w stosunku do ludzi i ludzie w stosunku do aniołów ${ }^{1}$. Podczas gdy aniołowie, kochając Boga, żyją błogo blisko Niego, stworzenie człowieka wywołuje pewien problem. Na pierwszy rzut oka chodzi tutaj o kwestię pozycji i w tej formie objaśniaja ją teksty. Aniołowie od samego początku podzielili się w nastawieniu do nowego zjawiska daje to możliwość wyjaśnienia upadku części z nich z powodu braku akceptacji dla stworzenia. Problem wyostrza się w islamskim micie Iblisa ${ }^{2}$. Iblis zajął wyższa pozycję i dzięki wyjątkowym zasługom znajdował się szczególnie blisko Boga, co stanowiło jednocześnie zagrożenie. Zabieganie o bliskość i wspomnienie zasług prowadzą do dumy, a ona do upadku (i do tego momentu ta paradoksalna opowieść służy za ostrzeżenie dla

\footnotetext{
${ }^{1}$ Zob. ściśle oparty na materiałach: Jung (1925).

${ }^{2}$ Por. szczególnie Awn (1983) wraz z dalszą literaturą na ten temat. Dodatkowo Calasso (1970: 71-90).
} 
religijnych gorliwców). Ten problem stał się palący wraz ze stworzeniem Adama. Bóg nakazał wszystkim aniołom, by się pokłonili Adamowi. Jeden z nich odmówił - czy to z powodu dumy, czy dlatego, że wiedział lepiej niż Bóg, że należy czcić jedynie Boga, doświadczając nakazu jako paradoksu, sprzeczności między samym nakazem a rzeczywistą wolą Boga (rozróżnienie stworzone dla wyjaśnienia jego zachowania). Uważał nakaz za test swojej wiary w Boga. Nieposłuszeństwo przyniosło mu wieczne potępienie, czyli oddzielenie od Boga. $Z$ racji tego, że od tej chwili stał się obserwatorem, mógł sobie je wyjaśnić jako dowód miłości Boga i nagrodę za długą służbę. Wyłącznie od niego można było wymagać, by stał się zły, ponieważ tylko on kocha wszystko, co Bóg czyni. Z tego powodu nie może wzbudzić w sobie żalu i tym samym będzie wiecznie potępiony. Wiedzie ludzi na pokuszenie, ponieważ uznaje to zadanie za sens swojego wygnania.

Jest to oczywisty przypadek podwójnego wiązania (double bind), a więc schizofrenii. Dzięki głębszej analizie można ponadto dostrzec, że chodzi tutaj o rywalizację w rolach obserwatora. W przeciwieństwie do aniołów, Adama od razu stworzono jako obserwatora, wyposażając go w nazwy rzeczy i tylko drażliwy schemat obserwacyjny moralności został przed nim ukryty. Aniołowie powinni się skłonić (gest uniemożliwiający im obserwowanie Adama). Iblis sprzeciwił się temu nakazowi, uzasadniając, że jest z ognia, zaś Adam jedynie z gliny. Nie odgadł, że jego natura jako (bezdymnego) ognia jest warunkiem bycia obserwowanym (odpowiednio „Lucyfer”), nie umożliwiając mu obserwowania. Został sprowokowany przez paradoksalny (z jego punktu widzenia) nakaz obserwowania i dokończył dzieło stworzenia, z pomocą węża i Ewy pozwalając Adamowi rozróżniać moralnie.

Oczywiście, jest to socjoteologiczna interpretacja o wiele prostszego mitu założycielskiego. Tym niemniej ukazuje ona, jak współczesne racjonalności, biegnące ponad semantyką stosunków pozycji, posłuszeństwa i dumy, służby i samolubstwa - i w tym sensie pouczające - są powiązane w złożoną kaskadę rozróżnień, pośredniczącą między perfekcyjnym metamoralnym monoteizmem a moralnościa, wyjaśniając genezę możliwości dokonywania rozróżnień przez człowieka. Główną rolę gra tutaj paradoks (rozwiązywalny tylko przez rozróżnienia). Ten ostatecznie arbitralny monoteizm można odczytać jako symbol transcendencji. Sens historii leży jednak nie tutaj, lecz w ustanowieniu moralności nieosądzającej z góry Boga.

Gdy porządek zostanie zaprowadzony (co zawsze oznacza dyfuzję „wielkiej tradycji” w społeczeństwie) i stanie się podstawą dla bieżącego przetwarzania informacji, wytwarza wiedzę, która możliwa jest w jego ramach. Zdarzenia zewnętrzne w stosunku do środowiska społecznego, doświadczane początkowo jako zakłócenia lub irytujące szumy, w schemacie moralnym systemu zostaja sklasyfikowane jako grzechy. System religijny, 
który kieruje się taką semantyką, będzie skłonny do uznawania społeczeństwa za grzeszne i traktowania go w perspektywie historycznej jako zepsucia początkowo świętego porządku. Na poparcie tej tezy istnieje wiele dowodów w świecie starożytnym. Również średniowiecze reagowało na mnożące się doświadczenia życia miejskiego, handlu, bogactwa i luksusu tendencja, która można określić mianem eksplozji grzechu³. Obsesja na punkcie grzechu wiąże się ściśle $\mathrm{z}$ instytucją spowiedzi oraz - z ogólnego punktu widzenia $-z$ profesjonalną troską o duszę. Niezbędnych generalizacji dostarcza tutaj przede wszystkim schemat grzechu pierworodnego. Z punktu widzenia teologii grzechem jest początkowo po prostu habitus, który skłania ludzi do tego, by wiedli życie niezgodnie z wolą Boga. Instytucja spowiedzi umożliwiła, a wręcz wymusiła powstanie poczucia winy co do grzechu, jego obserwację i uznanie za winę ${ }^{4}$. Z jednej strony, można zatem wykorzystać dogmat grzechu pierworodnego, który obejmuje wszystkich niezależnie od ich winy. Uprawnia on do założenia, że każdy musi chodzić do spowiedzi, nie dopuszczając wniosku, że ten, kto się spowiada, potrzebuje tego w szczególny sposób, innymi słowy, nie pozwala na umieszczenie spowiadającego się na szczególnej pozycji. To podejście umożliwiło odłączenie się od religii domowej, kultu przodków czy kultu zmarłych poprzez kościelnie zorganizowane „wstawiennictwo” za zmarłych, ponieważ bez schematu grzechu pierworodnego taka forma kultu stanowiłaby wyraz uderzającego lekceważenia ,grzesznych” przodków ${ }^{5}$. Z drugiej strony w spowiedzi rozwija się kazuistyka obarczania wina - od spowiadającego się wymagano samokontroli. Grzech pierworodny jako punkt wyjścia, porównywalny z zakazem odmowy oddania sprawiedliwości, zmusza do powstania profesji pewnego rodzaju uniwersalnej kazuistyki, przez której generalizacje można traktować problemy klientów jako swoje własne ${ }^{6}$. W dużej mierze każda profesja, która dba o swoje dobre imię, będzie musiała przedstawiać swoje zadanie jako „trudne”: grzechy sa

\footnotetext{
${ }^{3}$ Por. Spangenberg (1987). Podobnie co do tendencji, choć zupełnie inaczej w odniesieniu do semantyki, reagowała starożytna filozofia Platona i Arystotelesa na komercjalizację i demokratyzację życia miejskiego: moralną dewaluacja. Por. odnośnie do tego Spahn (1984). Jako brzemienny w skutki przypadek można widzieć to, że akurat ten rodzaj literatury się zachował i wpłynął na średniowiecze, podczas gdy teksty, które zabiegały o racjonalna „ekonomikę” gospodarstwa domowego w obliczu gospodarki pieniężnej i rynkowej, prawie całkowicie zaginęły.

${ }^{4}$ Wprowadzone w ten sposób niezwykle brzemienne w skutki (choć kontrowersyjne) ograniczenie będzie znaczące dla każdego, kto zajmuje się semantyką tego, co przeklęte. Por. (co prawda w odniesieniu do winy niewystarczająco selektywny) Ohly (1976).

${ }^{5}$ Odnośnie do podobnego problemu w stosunku chińskiego kultu przodków do buddyjskiej praktyki prośby za zmarlych por. Gernet (1978: 222).

${ }^{6}$ Rosengren (1970) określa to następująco: wytwarzanie convertible values [wartości wymienialnych], których można wymagać od klientów oraz odebrać im poprzez procesowanie wewnątrzprofesyjne lub wewnątrzorganizacyjne. Jako rekompensatę za wyznanie grzechów klienci otrzymują następnie w pewnym rodzaju semantyki wymiany - przekonanie o zbawieniu duszy.
} 
zakorzenione głęboko i silnie, nie jest łatwo uratować dusze. Nie istnieje żadna bezpośrednia droga od prostoty niewinności do złożoności cnotliwej pobożności. Poddane szumowi świata i spowiedzi sumienie deformuje się w przenikliwe wyrzuty sumienia oraz pedanterię w odniesieniu do unikania kontaktu z grzechem ${ }^{7}$, która w rezultacie może wywołać u obserwatora wattpliwości co do motywacji religijnej.

Ten schemat grzechów jest zatem odpowiedni jak żaden inny, by jednocześnie wypełniać wiele funkcji: odrzucić od społecznych centrów dyfuzję Wielkiej Tradycji, umożliwić bieżąca, profesjonalną opiekę nad ludnością odnośnie do problemów, które przez tę opiekę najpierw zostały wywołane, uruchomić rodzaj semantycznej ewolucji kazuistyki moralnej i przez to wszystko utrzymać silnie rozwinięte funkcjonalne wyodrębnienie się systemu religijnego. Jednocześnie ten schemat dawał również możliwość obserwacji systemu religijnego, gdyż zależy ona od sposobu, w jaki informacje są wewnętrznie przetwarzane. Wskutek tego od XIII w. stan grzechu zaczą coraz bardziej fascynować, odpowiadając obawie przed nieosiagnięciem życia wiecznego ${ }^{8}$. Zwiększały się odstępstwa i dystans w stosunku do normalnego zachowania i aprobaty moralnej. Stosując pojęcie wywodzące się z lingwistyki, można mówić o „hiperpoprawności”’. Przez wyznaczenie reguł, przykładów, portretów czy dawanie wzoru dobrego zachowania poprawiano nie tylko rzekomo pełne winy, grzeszne zachowanie, lecz także warstwa semantyczna tego, co prawidłowe, przesunęła się w kierunku ,jeszcze lepszego" i ,jeszcze pełniejszego" zrozumienia stanu faktycznego. Wizje piekła stają się coraz straszniejsze, bardziej drastyczne i dziwaczne, by przyzwyczajeniu przeciwstawić hartowanie i umacnianie się serca. Taki proces mógł przebiegać w cieplarnianych warunkach literatury, nie mając względu na prawdziwą zdolność motywowania, do czasu gdy w XVI/XVII w. samodzielnie skorygował się przez rozdzielenie silniejszych i łagodniejszych form obchodzenia się z grzechem.

Oczywiście w miejscu, gdzie zarządza się skarbem łaski, czyli w Rzymie, można było nadal utrzymywać, że jest ona obficie dostępna, a świat nadzwyczajnie urządzony. W każdym razie w kontekście renesansu do dyspozycji były środki retoryczne ${ }^{10}$. Odpowiednio traciły na znaczeniu wiara $\mathrm{w}$ Maryje, w cuda oraz wyrzuty sumienia $\mathrm{w}$ odniesieniu do

\footnotetext{
${ }^{7} \mathrm{Na}$ ten temat imponująca praca: Brun 1987.

${ }^{8}$ Por. Le diable 1979; Delumeau (1983 [polskie wydanie: Delumeau 1994]). Znaczący z naszego punktu widzenia jest bardzo wysoki udział faktów ekonomicznych, które ewokują świadomość grzechu. Por. Delumeau (1983: 246 i nn). Wprawdzie należy zwrócić uwagę, że już tradycyjny schemat grzechu chciwość-luksus-ambicja kierował uwagę w dużej mierze na fakty ekonomiczne, nie będąc zależnym od impulsów płynących z rosnącego dobrobytu gospodarczego. Zob. również Howard (1966).

${ }^{9}$ Por. co do przekazania ekspresyjnego zachowania: Van Parijs (1977: 138 i nn).

${ }^{10}$ Por. analizę kazań coram papa: O’Malley (1979).
} 
zbawienia duszy. Jednak nawet tutaj nie porzucono wyobrażenia upadku świata, a zagrożenie ze strony Turków mogło zwiastować nadchodzący koniec chrześcijaństwa.

Aż do XVII w. Europa żyła pod wrażeniem upadku, które sama wytworzyła; stopniowo dostrzegano wiele pozytywnych znaków postępu nowożytności ${ }^{11}$. W spowiedzi, ale także poprzez retoryczną technikę ukazywania cnoty i przedstawiania bohaterów, reprodukowano świadomość odstępstwa, która mogła kończyć się zachęta, ale i melancholia, w każdym razie społeczną rzeczywistość przedstawiano nieadekwatnie ${ }^{12}$. W opozycji do moralności zyskiwały popularność ważne innowacje strukturalne, które dotyczyły zachowania i semantyki.

Kiedy więc grzech krążył w systemie, wiążąc dające się zdiagnozować irytacje i tworząc przeciwciała, jak sama religia mogła reagować na wzmaganie się reakcji immunologicznej ${ }^{13}$ ? To pytanie prowadzi w skomplikowany sposób do historii powstania nowożytnego, zróżnicowanego funkcjonalnie społeczeństwa i zmusza nas, by jednocześnie mieć na uwadze więcej czynników: ponieważ religia jako podsystem w dużym stopniu już osiąnnęła zróżnicowanie funkcjonalne, tym samym stała się znaczącym, semantycznie wiodącym podsystemem społeczeństwa, a przez wyróżnicowanie się innych podsystemów została skłoniona do skomplikowanych przemian strukturalnych i semantycznych. Inne systemy funkcjonalne muszą narzucać swoją autonomię kontroli religijnej i nadawać sobie charakter „sekularny”, jeszcze respektując religię, a często skrycie nią pogardzając jako zacofana, okultystyczną materia. Sama religia nie może reagować adekwatnie (jak to sobie zawsze wyobrażano), lecz wyłącznie wedle tego, co nadaje sens jej własnemu systemowi. Tym istotniejsze jest pytanie, czy sposób, w jaki się to dokonuje, opóźnia czy przyspiesza przestawienie całego społeczeństwa na funkcjonalne zróżnicowanie.

\footnotetext{
${ }^{11}$ Charakterystyczna jest tendencja będąca w sprzeczności z tytułem książki (Le Roy 1577: 113 i nn). Ta często zauważana tendencja, by dostrzegać upadek, wcale nie opierała się na szczegółowym porównaniu starożytnych i nowożytnych prac czy bohaterów. $\mathrm{O}$ wiele bardziej zyskał na popularności retoryczny schemat rozdziału pochwały i nagany, który mógł być stosowany zależnie od okoliczności zarówno do starożytnych, jak i do nowożytnych. Można również z odniesień wnioskować o świadomości epoki, jak to zazwyczaj czyniła literatura, patrząc od querelle wstecz. Por. (Margiotta 1953, Buck 1973, Gössmann 1974, Black 1982).

${ }^{12}$ Postępująca nieadekwatność retoryki jako możliwości dysponowania moralnością wymagała gruntownej, prowadzonej teoretycznie analizy (Hardison 1962). Należy jednak w większym stopniu uwzględnić to, że retoryka utrwalała odstępstwa, a jej moralność uzmysławiała nienormalny przypadek, tak że należy liczyć się z pewnym rodzajem skutku nawrócenia: człowiek nie jest wprawdzie bohaterem, ale nie jest także tak zły jak łotr. $Z$ tego punktu widzenia interesująca jest praca Marinella (1600) z ukrytą teza, że damy rzadko osiagają w rzeczywistości swój poziom cnoty, podczas gdy mężczyźni są mniej źli, niż można by oczekiwać.

${ }^{13}$ Prowadzone z punktu widzenia teorii decyzji rozważania dotyczące kwestii, jak przy wzrastającym stanie grzechu można utrzymać ilość zbawienia przynajmniej na stałym poziomie (Lehner 1980).
} 
/// 5 .

Jak człowiek radzi sobie z dużą ilością grzechów? W samym systemie nie dopuszcza się do przekonania, że to system wytwarza grzech i w ten sposób reaguje na swój brak zrozumienia. Przyjmując samoobserwację systemu, odsłoniłoby ono strukturalny paradoks i doprowadziło do zatrzymania funkcjonowania systemu. Każde działanie byłoby jednocześnie za grzechem i przeciwko niemu. Na to może sobie pozwolić co najwyżej sam Bóg, a na pewno nie religia. Dla odciążenia religii paradoks musi zostać przeniesiony do transcendencji.

Również wówczas, gdy zagadka, jak Bóg może chcieć tego, czego nie chce chcieć, jest zniesiona w Bogu, nadal pozostaja nierozwiązane bardziej praktyczne problemy radzenia sobie z grzechem. Sa one tym bardziej naglące, kiedy nie można się ograniczyć do grzechów innych ludzi. Każdy jest dla siebie tym drugim jakiegoś innego drugiego, jest alter dla jakiegoś alter ego $\mathrm{i}$ w kontekście tej kosmiczno-moralizującej religii musi być świadomy własnego stanu grzechu.

W każdym razie teoria systemu religijnego z pewnych względów, które jeszcze zostaną omówione, wyciaga wniosek na temat tego, co mogą sądzić ci, którzy są zadowoleni z prowadzenia swojego życia w moralny sposób. Schemat grzechu funkcjonuje poprzez grzech pierworodny jako schemat dla komunikacji, a więc jako schemat samoobserwacji systemu społecznego; nie istnieje żadna pozycja, z której ktoś mógłby powiedzieć, że sam jest wolny od grzechu.

Świadomość grzechu jest generalizowana i w znacznym stopniu psychologicznie nieuwarunkowana. Kto uważa się za wolnego od grzechu, tym beznadziejniej jest w niego uwikłany. Kiedy jednak się napomina ta skłonność aż do XVII w. raczej przybierała na sile niż traciła - trzeba jednocześnie znać drogę wyjścia. Musi przynajmniej istnieć możliwość, by zrobić coś wbrew - albo po to, żeby religia pozostała w ramach psychologicznej możliwości, albo by uniknęła odkrycia całego teatru grzechu i ukazania się pluralistic ignorance, nierozpoznaniem prawdziwych motywów i nastawienia innego człowieka.

Późne średniowiecze eksperymentowało z dwoma bardzo odmiennymi rozwiązaniami tego problemu. Najpierw zwiększało sprawność mechanizmów, które mimo wszystko otwierały grzesznikowi Królestwo Niebieskie. Mógł on próbować pozyskać dla siebie Maryję lub dzięki opanowaniu ars moriendi osiagnąć to, że nie umrze w stanie grzechu. Z kapłańską pomocą w wierze mógł się wewnętrznie zasugerować, że żałuje swoich grzechów. Mógł wyprosić rozgrzeszenie i je otrzymać ${ }^{14}$.

\footnotetext{
${ }^{14}$ Por. z materiałem z obszaru kultu świętych i kultu maryjnego Spangenberg (1987).
} 
Wszystkie te strategie sa bez wyjątku wysoce refleksyjne, próbując manipulować systemem od dołu.Jeśli bezgrzechu nie jest to możliwe, to trzeba się przyjrzeć, jak można to zrobić z nim, a Kościól jest tym samym zmuszony do odpowiedzi, której nie może uniknąć. To wciąż poddawane obserwacji niezwykle pragmatyczne obchodzenie się z rzeczami świętymi przeniosło się $\mathrm{z}$ rytuału na pragmatykę zbawienia. Kościól, który wywołał tę problemową sytuację, nie może sprzeciwić się oczekiwaniu, by oferował rozwiązania dla przetrwania. Może on nie całkiem oddać świat diabłu, który w imieniu sprawiedliwości grzeszników protestuje na rzecz piekła. Dramatyzacja grzeszności prowadzi ostatecznie do tego, że sam diabeł może zachowywać się jak zdrajca sprawiedliwego porządku i należącej do niego kary (Russell 1984: 80 i nn.). Może zakraść się do moralności przez naleganie na moralnie nienaganne prowadzenie życia, w ten sposób powodując bezkrytyczną arogancję i doprowadzając do tym pewniejszego upadku. Warunki ratunku przenoszą się w sferę irracjonalności, a z osobliwej okazjonalności i „systemowej niezgodności” dróg wyjścia można odczytać, jak silny musiał być ten nacisk.

Ponieważ istnieje poza tym również teologia, ta „refleksja od dołu” nie jest całkowicie pozostawiona sama sobie. Konkuruje ona niejako z „refleksją od góry", z teoretycznym autoopisem systemu. Teologia czuje się zobowiązana, by pozwalać na więcej, jeśli coś wydaje jej się dobre. Zastanawia się jednak również nad swoimi własnymi rozwiązaniami. W tych staraniach rozpoczęto oddziałujące po dziś dzień rewizje podstaw, widocznych w rozłamach kościelnych, które wzięły się z teologii. Ich sensacyjność i konsekwencje przykryły to, że istniały również inne reakcje, które w znacznym stopniu odpowiadały wzorowi, za pomocą którego inne systemy reagowały na różnicowanie funkcjonalne. Zróżnicowanie funkcjonalne wymaga „silniejszego różnicowania i reintegracji kodowania i programowania" w pojedynczy system funkcji. Ta tendencja jest widoczna również w religii i prowadzi do rozpadu kosmologicznie ufundowanej moralności, która, jak pokazano, dźwigała dotychczasową semantykę religii, odnoszacą się do świata i społeczeństwa.

Kosmologiczna moralność zakładała związek między dobrym lub złym zachowaniem a perspektywami na życie po śmierci. Troszczyła się o odpowiednie miejsce przeznaczenia, rozróżniała niebo i piekło, zbawienie i potępienie, poprawiała niekompletność sankcji moralnej. W porównaniu do antycznych fatalizmów ${ }^{15}$, schemat zbawienie lub potępienie musiał

\footnotetext{
${ }^{15}$ Fakt, iż było to osiagnięcie ewolucyjne, widać po tym, że wiele starożytnych religii pytanie o możliwość i sposób dalszego życia po śmierci przez przyczynowość przyłączania uczyniło zależnym od samych okoliczności śmierci, a nie od całościowej oceny biografii. Por. np. Führer-Haimendorf (1953); Barth (1975: 127). Wraz z przejściem do oceny całościowej jako punktu wyjścia dla późniejszego losu, wzrastała różnica, którą można było sobie wyobrazić między życiem tutaj i po drugiej stronie.
} 
działać jak oswobodzenie. Wiadomo było (gdyż zostało to objawione), w jaki sposób osiagnąć zbawienie. Była to z pewnością nieodzowna, bezkonkurencyjna innowacja semantyczna. Tam, gdzie autentyczne źródła tego nie podaja, teologia jest wystarczająco konsekwentna, by poprawiać teksty - mniej więcej tak, jak z Ewangelią według św. Mateusza (25,31 i nn). Integracja religii i moralności nie funkcjonowała już perfekcyjnie, gdy społeczeństwo stało się bardziej złożone, a jego moralność wieloznaczna lub też gdy system religijny się wyróżnicował i nie mógł w pełni narzucić własnych postulatów moralnych polityce czy warstwie arystokratycznej. Semantyczna jedność zasad moralnych nie pasowała do funkcjonalnego różnicowania.

Zastrzeżenia ukazują się już we wspomnianym wyżej fragmencie Ewangelii. Sąd Ostateczny nadchodzi niespodziewanie, dzieląc grzeszników i sprawiedliwych na podstawie końcowego położenia, które ich czeka. Nie jest to zgodne z powszechną moralnością i zainteresowani mogli tego nie przewidzieć. Nie jest to sprawiedliwe, ponieważ przyniosłoby piekło wszystkim, w tym ludziom dobrym ${ }^{16}$. Tekst jest niekonsekwentny o tyle, o ile nie rozważa siebie jako tekstu, będąc objawieniem przynajmniej u czytelników znosi zaskoczenie, na którym się opiera ${ }^{17}$. Nie powinno być to jedynie omyłkowo ocenione samoodniesienie, które zdradza tekst i pozbawia go mocy; w tym niepowodzeniu znajduje się raczej wskazanie na to, że problem w formie ,zaskoczenia”, a zatem w formie informacji, nie jest odpowiednio traktowany. To, co deklarowane jest jako zaskoczenie, jest w rzeczywistości problemem, który nie może rozwikłać moralnego kodowania religii na dobro i zło - problemem, który rozsadza ten kod i wskazuje na inny rodzaj kodowania, tj. na różnicę oceny immanentnej oraz transcendentnej: podstawę Sądu Ostatecznego stanowią inne kryteria niż moralny osąd w świecie ${ }^{18}$. Jak jednak można opisać jedność społeczeństwa, jeśli tak jest?

Filozoficznie imponujące rozwiązanie tego problemu można odnaleźć u Mikołaja z Kuzy. Za jego podstawę bierze on problem rozróżniania

\footnotetext{
${ }^{16}$ Maria przed swoim Synem, Sędzią Świata, opowiadała się przeciwko diabłu - nawet jeśli w niezbyt typowy dla sądu sposób - tj. łzami i wskazaniem na macierzyństwo itd. (Gros 1979: 237-258).

${ }^{17}$ Również inne teksty biblijne przedstawiają zaskoczenie, w ogóle nie rozważając, że tym samym wyklucza się jego powtórzenie. Po tym, jak ofiara Izraela została przeniesiona i uniemożliwiona, a powtórne działanie tego rodzaju jest wykluczone, pozostaje jedynie samopoświęcenie Boga, które w swojej jedyności raz na zawsze dało możliwość, by żyć i umrzeć zgodnie z wolą Boga.

${ }^{18}$ Por. interpretację Scholza (Scholz 1987: 107-136). Nawiazzuje on do momentu zaskoczenia i odczytuje go jako wskazanie na to, że zbawienie nie nadejdzie na podstawie uwarunkowań, lecz leży w akceptacji samej Ewangelii. Teologiczny wynalazek Sądu Ostatecznego jest tym samym w szczęśliwy sposób unieważniony i zastąpiony powołującym się na siebie argumentem: Ewangelia mówi, niech się stanie Ewangelia. Pozostaje pytanie, przez jakie rozróżnienie ta tautologia zostanie rozwiązana.
} 
rozróżnień oraz pojęcie Boga, które poprzedza wszystkie różnice ${ }^{19}$. Wyrok Chrystusa pozostaje nieprzewidywalny i niepojęty (nawet gdy można go opisać), ponieważ osądza on jednostki nie przez pryzmat ich wzajemnej odmienności, czyli nie przez porównanie, lecz przez pryzmat ich indywidualności ${ }^{20}$. Ich pojedyncze istnienia, ich non aliud pozostaje nierozpoznawalne w stosunku jednostek do siebie nawzajem i otwiera się jedynie na łaskę. Tutaj leży nieużyteczność łaski w praktyce społecznej. Nastawienie na rozróżnienie zbawienia i potępienia, a być może nawet wyobrażenie życia po śmierci, jest przydatne jedynie wówczas, gdy można wiedzieć już w teraźniejszym życiu, od czego zależy życie pozagrobowe. Kryteria muszą być znane i przydatne praktycznie. Na początku XVIII w. jezuici sądzili, że to całkiem prosta sprawa ${ }^{21}$, jednak obecnie taki pogląd jest już anachroniczny. Jedność moralności nie nadąża już za rozwojem złożoności społeczeństwa i odkrywaniem paradoksów moralnych. Prawo naturalne przestawia swoją argumentację z oczekiwania zbawienia duszy na oczekiwanie korzyści ${ }^{22}$, a niepewność odnosi się do nieprzewidywalnej przyszłości na tym świecie. Gdy nie można założyć konsensusu moralnego (chociaż w ramach sekt lub wyznań), orientowanie się na życie po śmierci w znacznym stopniu traci swój sens lub dewaluuje się do prostego wyobrażenia pociechy w obliczu śmierci.

Rozwiązanie, które pojawia się od średniowiecza, można opisać przede wszystkim jako podwójne kodowanie moralności. Podkreśla ono konieczność łaski Bożej. Dołączyło ono do moralnego rozróżnienia na dobre i niedobre (w wersji zsubiektywizowanej: na dobre i złe), lecz nie ujawnia na razie kwalifikacji moralnej. Grzesznik pozostaje grzesznikiem, ale może mimo to mieć nadzieję na zbawienie, jeśli jest świadomy swoich grzechów i za nie żałuje ${ }^{23}$. Z drugiej strony nawet sprawiedliwy nie może być pewien swej sytuacji. Musi zastanawiać się zgodnie z drugim kodem, jak

\footnotetext{
${ }^{19}$ Por. Mikołaj z Kuzy (1964a: 56). Bóg jest „,ante omnia quae differunt”. W dalszych wyjaśnieniach odnaleźć można przede wszystkim rozróżnienie byt-niebyt czyli ontologię, a nie biorace się z. moralności roz̧różnienie dobre - żłe. Najwyraźniej Bóg jest obojętny odnośnie do rozróżnienia na byt i niebyt, ale nie co do rozróżnienia dobrego $i$ złego.

${ }^{20}$ Por. Mikołaj z Kuzy (1964b: 486) (non discussione comparativa vel praesumptiva ac prolatione vocali ac signibus talibus). Dlatego poza czasem i w zejściu się sądu oraz zmartwychwstania.

${ }^{21}$ Por. na przykład Villiers (1700-1702).

${ }^{22}$ Zob. na temat tej różnicy między Seldenem a Hobbesem - (Tuck 1979: 94, 127).

${ }^{23}$ Por. Payen (1967). Niezbędne do tego warunki są przeciwieństwem szczegółowej i drobiazgowej dyskusji nad tym, czy wystarcza sam strach przed piekłem (attritio), czy też musi dojść do niego szczera skrucha; i dalej, czy wystarcza żal za przeszłe grzechy, czy też należy uwzględnić przyszłość w tym znaczeniu, że późniejsza skrucha może okazać się nieszczera, kiedy grzesznik nie podtrzymuje decyzji o lepszym prowadzeniu życia. Jednak jak zawsze szczegóły: cała konstrukcja zakłada nienaruszona moralność, której człowiek może się trzymać. Szczególnie jezuici nie ustawali w podkreślaniu, że każdy może sobie na to pozwolić. (Por. na przykład Villiers 1700-1702: t. II,93, 104 i nn.) Jednocześnie skończono ze szczególnymi szansami kapłanów lub mnichów. Niebo i piekło są otwarte dla każdego.
} 
to z nim jest przy wszystkich staraniach, by żyć nienagannie. Jego grzechy mogłyby polegać na tym, że jest nazbyt pewny swojej moralnej wartości i chce sam osiągnąć to, co może zostać osiąnnięte jedynie dzięki łasce Bożej. Jak pokazała siedemnastowieczna dyskusja o szczerej i fałszywej pokorze, nie można zdobyć w tej kwestii ostatecznej pewności, ponieważ specyfika fałszywej pokory jest to, że bazuje na samooszukiwaniu i nie potrafi się przejrzeć ${ }^{24}$. To rozwiązanie zakłada, że różnica między zbawieniem a potępieniem została przeniesiona do transcendencji, stamtąd wypełniając funkcję łączenia. Służy na tamtym świecie jako moralny ekwiwalent dla tego, co na tym świecie rozgrywa się pod wpływem społecznej moralności. Z punktu widzenia religii należy zmienić stosunek pierwszego i drugiego kodu. W religii - zgodnie z jej tradycjami chodzi przede wszystkim o różnicę immanencji i transcendencji, która jest dopełniana i operacjonalizowana za pomoca drugiego kodowania moralnego. Religia może się ostatecznie dać pogodzić z rozwojem historycznym każdej moralności oraz ze względnościa wszystkich znaczeń moralnych, choć trudno, by pragnęła, żeby należało to do społeczeństwa. Tylko to, że w ogóle można rozróżniać między dobrym a złym, jest dla niej niezbędne jako kod binarny. Poszczególne programy szacunkupogardy w moralności moga się zmieniać. Religia jest związana świętymi tekstami swojej tradycji, co jednak wywołuje problemy, ponieważ utrwalały one zawsze również współczesne im wyobrażenia moralności, tak więc obecnie wymagają interpretacji. Jedną z możliwości sprzęgnięcia obydwu kodów jest temporalizacja stosunku czasu i wieczności (czyli immanencji i transcendencji). Z perspektywy indywidualnego życia różnica zostanie zaznaczona przez śmierć. Ma się czas do śmierci, potem rozpoczyna się wieczność. Do swojej śmierci jest czas, by się moralnie sprawdzić lub też zawieść, a potem na wieczność dźwiga się konsekwencje i nie można już nic zmienić (Nierembert 1676). Moralności doświadcza się jako pokusy. W obliczu grzechu pierworodnego najlepiej jest oczywiście umrzeć zaraz po narodzinach, o ile chrzest zapewni ocalenie duszy ${ }^{25}$. Początkowo pytanie, jaka moralność prowadzi do jakiej wieczności, nie jest problematyczne. We frapującej analogii do rozwoju innych systemów funkcjonalnych system religijny również zdaje się zatem poszukiwać podwójnego kodowania, dzięki

\footnotetext{
${ }^{24}$ Po stronie katolickiej odgałęzia się wariant teorii spowiedzi, zakładający, że człowiek właśnie dlatego musi zdać się na swojego duchowego doradcę, directeur de l'âme [przewodnik duszy], który może sobie wyrobić opinię z zewnątrz, na podstawie swojego profesjonalnego doświadczenia. Dla purytanina niezbędna jest wypełniająca podobną funkcję teoria zewnętrznych wskaźników, które wskazują na powołanie do życia wiecznego.

${ }^{25}$ Jak relacjonowali jezuici z Pekinu, co roku porzucano i zostawiano na śmierć 20000 do 30000 noworodków. Każdego dnia zakon wysyłał swoich katechetów, ale było ich zbyt mało. Udawało się ochrzcić maksymalnie ok. 3000 dzieci, zanim umarły. Zob. Noel (1780-1781: 166 i nn.).
} 
któremu można podkreślić wartość własną (Eigenwert) religii i ostatecznie wyróżnicować jej wiodące operacje. W przypadku gospodarki analogia leży $\mathrm{w}$ drugim kodowaniu własności przez pieniądze, w przeformułowaniu różnicy posiadanie-nieposiadanie na różnicę płacenie-niepłacenie, która w efekcie „likwiduje” cały porządek własności starego świata. W systemie politycznym analogia polega na drugim kodowaniu władzy politycznej przez prawo, zgodnie z którym oficjalne władze mogą zostać zmobilizowane do wprowadzenia w życie za pomocą siły fizycznej decyzji każdego, kto ma prawo (ja wydać), podczas gdy z drugiej strony, osoba pełniąca dana funkcję może prawomocnie działać jedynie w ramach prawa. Drugi kod prawa-bezprawia całkowicie przekształca dostęp do przeważającej władzy politycznej, redukując go do dostępu zgodnego z prawem i tym samym znacznie ów dostęp poszerzając, ponieważ prawo - podobnie jak pieniądze - może realizować znacznie większą zdolność generalizacji i tworzenia oczekiwań niż sama przemoc.

We wszystkich tych przypadkach drugie kodowanie zależy od dalszego funkcjonowania pierwszego kodowania. Pieniądze są bez własności tak samo nie do pomyślenia, jak prawo bez zabezpieczenia fizyczna władzą przymusu i terytorialnie przeważająca kontrolą polityczną ${ }^{26}$. Chodzi tutaj o dodatkowe warunki, które staną się moźliwe i sensowne, kiedy funkcjonalne zróżnicowanie pogłębi się i wywoła dostateczna złożoność. To porównanie wskazuje jednak jednocześnie, gdzie sytuują się problemy dotyczące wyodrębniania się religii. Drugie kodowanie wymaga podstawowego kodu moralności. Zakłada ono istnienie funkcjonującej różnicy między zbawieniem i potępieniem oraz dotyczy jedynie nastawienia religijnie zdezorientowanego, a następnie ponownie konstruowanego na moralna jakość własnego zachowania. Swoboda funkcjonowania kodu jest ustanowiona przez ustanowienie wymiaru pewności: najpierw poprzez negację niepewności co do zbawienia i potępienia ku pewności w odniesieniu do społecznych standardów moralności.

Pytanie o współdziałanie religii w genezie nowożytnego społeczeństwa jest $\mathrm{w}$ istocie rzeczy pytaniem o skutki tej przestrzeni dla podwójnego kodowania, jak również o skutki kodu przez nią oferowanego. Można zaobserwować przynajmniej dwa pośrednie szeregi oddziaływań, tj. społeczne zezwolenie na wyższą amoralność oraz tendencję do indywidualizacji całkowitej odpowiedzialności jednostki za samą siebie. Ograniczamy się tutaj do tego pierwszego zjawiska [...].

\footnotetext{
${ }^{26}$ Należy odróżnić kodowanie podwójne od kodowania zastępczego, które pojawia się wówczas, gdy pierwszy kod nie działa wystarczająco - na przykład prywatne oddziały dla zabezpieczenia jeśli nie pokoju, to własnych interesów itp.
} 
Wraz z własnym podwójnym kodowaniem stosunku do moralnej podstawy zachowań społecznych religia wychodzi naprzeciw tendencji innych obszarów funkcjonalnych $-\mathrm{z}$ pewnością tego nie chcąc - by ze swej strony oddzielić się w krytycznych przypadkach od zobowiązań moralnych. Można to obserwować w sferze dyskusji o „racji stanu” czy też w niepowstrzymanym wzroście namiętnej miłości. Wprawdzie zasady polityczne Machiavellego zwalczano gorliwie jako hańbę natury religijnej i moralnej, ale można odnieść wrażenie, że oburzenie kwitło jedynie w literackiej cieplarni. Machiavelli dobitnie sformułował to, co zaaprobowano $\mathrm{w}$ postanowieniach soborowych Kościoła katolickiego chodzi tu o uzasadnienie morderstwa Jana Husa w Konstancji ${ }^{27}$, a w XVII w. nikt więcej nie negował tego, że coś takiego jak ius eminens należy jeśli nie do „statusu” księcia, to do koniecznych przywilejów władzy państwowej. Z punktu widzenia nauki chrześcijańskiej rady dawane przez „perfidnego” Machiavellego jako prawo do złamania prawa ze względu na wyższą korzyść stały się przywilejem państwa ${ }^{28}$, przeciwko czemu rozwijano następnie $z$ cała prawniczą biegłością konieczne środki ochrony ${ }^{29}$. Moralne oburzenie działa jak zasłona, faktycznie chodzi zaś o ocalenie dogmatu o szczególnej opatrzności Bożej, zwłaszcza w kontrreformacji, przeciwko zasadniczo antyprowidencjonalistycznej, okazjonalistycznej teorii praktyki politycznej ${ }^{30}$. Dogmat musiał obejmować cała politykę ${ }^{31}$, podczas gdy religia coraz bardziej traciła dostęp do merytorycznych problemów. W tej sytuacji korzystne mogło być rozstrzygnięcie sporu na gruncie moralnym i zadowolenie się wyrażeniem oburzenia i pogardy.

Teorię namiętności i afektów również określa prymat schematu moralności. Ponieważ ponad pasjami i afektami istnieją motywy, nie znaczy to jednak, że podobnie jak w tradycji stoickiej namiętności oceniane byłyby w kategoriach moralnych. Są one elementem stworzenia i można je wykorzystać zarówno dobrze, jak i źle. Podobnie rzecz się ma w kolejnym podziale: na miłość i nienawiść. Nie da się już jednak osiagnąć zgodności w znaczeniu miłość-dobro, a nienawiść-zło. Różnica, jaką wprowadził na świecie grzech pierworodny, sprawiła, że miłość jest równie ambiwalentna jak nienawiść. Obydwie te namiętności zawierają cechy moralnie pozytywne

\footnotetext{
${ }^{27}$ Odnośnie do ciagłych linii tradycji por. przede wszystkim pracę: Mattei (1969), a także Bonucci (1906).

${ }^{28}$ Zob. wraz ze spornym wyjątkiem prawa naturalnego (Spontone 1599: 13, 17 i nn., 138).

${ }^{29}$ Por. np. Gierke (1958: 268 i nn., Stödter 1933: 57 i nn., Luhmann 1965: 37 i nn.). Ograniczenie takiego prawa nie musiało być bezwzględnie nieprzyjemne dla księcia, jak - przestrzegając przed tworzeniem legend XIX w. - pokazuje Ogorek (1984).

${ }^{30}$ Podkreśla to Ceñal (1951: 61-67). Trzeba prócz tego spostrzec, że stabilność reżimu politycznego w Hiszpanii dawała mniejszą okazję wywodzącej się stamtąd kontrrewolucji do wczucia się w sytuację polityczną Machiavellego. (Mora 1949: 417-449).

${ }^{31}$ Por. na przykład Mesnard (1953: 109-116).
} 
i negatywne. Miłość własna jest początkowo jedynie autoreferencja własnej tożsamości, lecz może zmienić się w coś niedobrego i pożądliwego. Nienawiści do samego siebie nie uważa się za coś dobrego, ale może być ona dobra i uzasadniona, jeśli zwraca się przeciwko grzechom ${ }^{32}$. Miłość i nienawiść nie są zatem moralnie definiowalne jako zdolności umysłowe dlatego, że różnica moralna pojawiła się na świecie jako grzech. Ze względu na religijną podstawę moralność celuje w stopniowanie miłości i nienawiści, za każdym razem eliminując te formy, które nie moga zostać przez nia zaakceptowane. Jakie to będą formy, jeśli również inne systemy funkcjonalne zaczynają formułować wymagania w stosunku do moralności?

Co się tyczy namiętności, a szczególnie namiętnej miłości, to wedle dawnej doktryny można je zwalczyć, dokładając wszelkich starań; do rozsądnego i moralnego prowadzenia życia niezbędne jest opanowanie namiętności. Z drugiej strony samo pojęcie namiętności nadawało się do wyrażenia intensywności oraz zażyłości związków religijnych. W dużej mierze pojęcie namiętności dlatego wywołuje religijną fascynację, ponieważ zajmuje dziwną, wieloznaczną pozycję, początkowo między res corporales i incorporales ${ }^{33}$, działaniem wewnętrznym i zewnętrznym, rozsądkiem a zmysłami ${ }^{34}$, a od XVII stulecia również między podejściem aktywnym i biernym, między znajdowaniem się pod wpływem a własną dynamiką. Te wieloznaczności stanowią typowe ognisko religijnego wytwarzania symboli i unikania paradoksów. W tym przypadku można było się najpierw trzymać reguły, że wartość (rozumianej biernie) namiętności zależy od wartości przedmiotu, który ją wywołał ${ }^{35}$. Namiętność była zatem z jednej strony możliwa do umieszczenia w hierarchicznej strukturze świata, mogła też zostać odniesiona do piękna kobiety. Przez „aktywizację” namiętności ${ }^{36}$, która zyskiwała popularność od połowy XVII w., załamała się możliwość takiej konstrukcji. Namiętność ustanawiała się sama i możliwe było, że powstawała na drodze iluzji odnośnie do cech jej przedmiotu. Stała się ona punktem wyjścia własnej architektury moralnej, która naśladowała hierarchiczny schemat, służący za podstawę świata (Luhmann 1989: 277 i nn.): namiętność jako taka jest moralnie obojętna, ani dobra, ani też zła. Można ją wykorzystać dobrze lub źle, wymaga ona kontroli rozsądku ${ }^{37}$. Nadal jednak præ̌edmiot namiętności kwalifikował ją jako

\footnotetext{
32 „The principal object of a right hatred Sin”, jak stwierdził Reynolds (1971: 142).

${ }^{33}$ Por. na ten temat oraz odnośnie do sporu o współistotność duszy i ciała (Chenu 1974: 11-18).

${ }^{34}$ Zob. jasno wskazujący na betwixt [pomiędzy]: (Wright 1971: 7 i nn.).

${ }^{35}$ Powszechnie uznawane jeszcze w XVII w. Zob. np. Reynolds (1971: 32 i n., 51 i n.).

${ }^{36}$ Szczególnie wpływowym dziełem były Namietności dusay Kartezjusza z $1649 \mathrm{r}$.

${ }^{37}$ Podobnie (przeciwko stoikom) Wright (1971: 15 i nn.). Również Senault (1641 datowanie cenzury) traktował przekazaną systematykę namiętności wedle tego wzoru. Zob. Senault (1641: 1 i n., 124 i nn.). Odpowiadało to doktrynie średniowiecznej: namiętności sa „,podmiotem” cnoty, tzn. są kwalifikowane dzięki cnotom lub przywarom.
} 
dobrą lub złą. W XVIII w. ocenę moralną uzależniono wyłącznie od skutków kierowanego namiętnością zachowania. Następnie dodano nowe, modne pojęcie dla aspektów pasywnych: pojęcie wrażliwości. Również ono było moralnie dwuznacznie kwalifikowane jako pojęcie dystansowania i stopniowania moralności: „dusze wrażliwe posiadaja więcej istnienia niż inne: rzeczy dobre i złe zwiększają je” (Duclos 1970: 235). Po przesunięciach semantycznych potrzebna była tylko modyfikacja: wyobrażenie, że jeden jedyny obiekt wywołuje namiętność lub też został do tego wybrany, a wszystkie paradoksy, które przez religię zostały włączone w kult, okazują się ujawnioną semantyką szczególnego kodu namiętnej miłości, która jako „suweren” we własnym zakresie sprzeciwia się rozsądkowi i moralności (Luhmann 1982: 57 i nn., wydanie polskie: Luhmann 2003). Religia już wcześniej została rozbrojona - tak bardzo chciano podkreślić $\mathrm{w}$ dawnej pilności, że dla opanowania namiętności niezbędne jest secours surnaturel ${ }^{38}{ }^{39}$. Inna droga pojmowanie interesów gospodarczych wyzwoliło się od kompleksu grzechu avaritia ${ }^{40}$, pleoneksji i źle skierowanych namiętności (Hirschman 1980). Oto nowe pojęcie interesu ${ }^{41}$, który służy do dyscyplinowania namiętności, nie odsyłając do secours surnaturel. Podobnie jak plaisir ${ }^{42}$, zawiera ono rodzaj autoreferencji, która nie akceptuje żadnych zewnętrznych kryteriów (czy to religijnych, czy moralnych). Jedynie ten, kto się czymś interesuje, może powiedzieć, co czyni i co jest przedmiotem jego zainteresowania. Jednocześnie musi rozwijać interesy, by formować swoją naturę. Kto zaprzecza własnym interesom, tym samym ściaga na siebie podejrzenie ${ }^{43}$; będzie jawnie uchylał się od społecznej kalkulacji, komercji interesów. Arbitralność określenia interesów pozostaje wprawdzie zakryta do XVII w., ponieważ początkowo ma się na względzie jedynie obiektywne pożytki czy korzyści, w każdym razie to pojęcie uprzytamnia możliwości kalkulacji w obszarze polityki i gospodarki, które są zakotwiczone w rzeczywistości, a nie w moralności.

\footnotetext{
${ }^{38}{ }^{39} \mathrm{fr}$. nadnaturalna pomoc.

Tak u pisarzy moralnych, jak np. Des Coustures (1687: 168). Wyżej omówiona ambiwalencja zyskuje poza tym popularność również w tym aspekcie: miłość własna (amour propre) wyjaśniano grzechem pierworodnym (Des Coustures 1687: 81 i n., 167 i nn.), a morale universelle miłością własną jako jedyną namiętnością ludzi. Grzech jako podstawa moralności i grzech pierworodny jako warunek możliwości wszechświata, który się moralnie udoskonala! Analogicznie: współczesny optymizm i krytyka teorii ,złotego wieku” oraz historia jako upadek. Dawniejsze epoki nie były szczęśliwsze niż dzisiejsza! (s. 218 i nn.).

${ }^{40}$ łac. chciwość.

${ }^{41}$ Generalizacja tego pojęcia zdaje się, w każdym razie we Włoszech, rozpoczynać już w XV w. Zob. np. z drugiej połowy XV w. Pontano (1556: 792-931; 806: „Quantum nostra interest, atque ad nos ipsos spectat"). Por. także Gerhardt (1976: 479-494). Przeciwstawianie interesu prywatnego i dobra publicznego jest starsze, niż się często przyjmuje np. Spontone (1599: 212).

${ }^{42}$ fr. przyjemność, rozkosz.

${ }^{43}$ „Robić podejrzane sztuczki”, jak stwierdził Silhon (1661: 103).
} 
Przez to pojęcie można ucieleśnić nieskończoność, przede wszystkim jako dążenie do większej ilości pieniędzy, które w przeważającej mierze zdaje się sensowne i uzasadnione. Siedemnastowieczna teoria gospodarki zaczęła się tym interesować wyłącznie z powodu ekonomicznych restrykcji racjonalnego zastosowania kapitału.

W miarę, jak obszary funkcjonalne porzucały grzech z powodu semantycznych manewrów tego rodzaju i akumulowały we własnym kodzie doświadczenia sukcesu, pojawił się optymizm co do postępu, który wpłynął na doktrynę grzechu pierworodnego. Została ona pod koniec XVII stulecia ponownie oceniona pozytywnie, włączona w dyskusję o teodycei i tym samym skorzystała na (ledwie do uniknięcia) usprawiedliwieniu Boga ${ }^{44}$. Grzech pierworodny zakończył ekonomiczno-społeczną stagnację raju i stał się warunkiem postępu. Można niemal powiedzieć, że zaznaczył przejście do gospodarki pieniężnej, która umożliwiła powstanie większej ilości pracy, koniecznej dla utrzymania, oraz wykorzystanie pracy dodatkowej dla zysku i poprawy sytuacji życiowej ${ }^{45}$. Został uroczyście określony jako forma umowy (covenant) między Bogiem i Adamem (Gouge 1690: 30 i nn.) (widocznie w owocowym delikcie chodziło tylko o to, by postawić Adama w niekorzystnej pozycji negocjacyjnej). Stała formuła grzechu, contemptus Dei, okazała się elastyczna - można ją było mieć przy sobie jako zignorowanie oferty Boga, gdy istniało jeszcze wiele innych, być może pilniejszych problemów do rozwiązania. W ten sposób można było porzucić doktrynę jako teorię ontologicznej korupcji ludzi i zastapić ją wyobrażeniem dekadencji lub cywilizacji. Jak osądził Charles Hall na podstawie swojej dokładnej znajomości położenia warstw pracujących w Anglii: „uważam, że wszystko lub prawie wszystko, co nazwano pierwotnym zepsuciem i dyspozycja do zła, jest rezultatem systemu cywilizacji, a szczególnie tej jego znaczącej cechy, jaką jest wielka nierówność własności” ${ }^{46}$. Równolegle - i także pod koniec XVIIw.-moralność stała się przedmiotem własnego zainteresowania, a nawet stanowiskiem, które umoźliwiło ocenianie religii ${ }^{47}$. Odwrócenie pozycji, stawiające moralność nad religia, oznaczało, że problemy religijne mogą koncentrować się na religii, a wszystkie inne systemy funkcyjne, jak

\footnotetext{
${ }^{44}$ Por. Marquard (1981: 53-71). Sformułowanie i temat paradoksu felix culpa ma korzenie antyczne, służyły one jednak najpierw wychwalaniu Chrystusa i Jego dzieła zbawienia, a dla teodycei zyskały znaczenie po raz pierwszy w XVII w.

${ }^{45}$ Por. z perspektywy społeczno-antropologicznej i szczególnie odnośnie do wzrostu pracy w czasie ewolucji Sahlins (1968: 79 i nn.).

${ }^{46}$ Hall (1965: 269 i n). Aranżowanie grzechu pierworodnego przez Boga jest dla dzisiejszego autora ,jednym z jego praktycznych żartów, obawiam się, że w niezbyt dobrym smaku”. Podobnie Keys - alias G. Spencer Brown - (1971: 24). To oznacza w dużej mierze, że każdy optymizm odnośnie do skutków jest niestosowny.

${ }^{47}$ Często opisywany problem. Por. szczególnie Certeau (1972: 31-94). Przykład wpływowego tekstu z XVIII w. zob. przede wszystkim Anthony, Earl of Shaftesbury (1968a: 1-176).
} 
sama religia, społecznie muszą się liczyć jedynie z problemami moralnymi. W stuleciu moralności, tj. w XVIII w., społeczeństwo pozwoliło przedstawiać się w społeczeństwie poprzez moralność. Na miejsce strachu przed piekłem wkroczył strach przed śmiesznością, który zakładał istnienie sprawnego, stanowego społeczeństwa ${ }^{48}$. Z tego punktu widzenia religia stała się sprawą wymagającą wyjaśnienia, historyczną warstwą niepotrzebnych zawiłości, źródłem sporów i nienawiści, maską dla chęci rządzenia, ideologia - lecz również pozytywnie: formą kanonizacji spornych tekstów i poglądów (Shaftesbury) lub środkiem udomowienia i wychowania niższych warstw społecznych.

Kiedy moralność w ten sposób wzniosła się ponad religię, nie mogła uniknać pojawienia się w swoich ramach paradoksów, które tamta zasłoniła. Kiedy w myślach eksperymentowano z moralnością, w pojęciu Boga znów pojawiły się paradoksy i obwieszczono podłość lub też śmierć Boga. Podobnie u Sade'a: ,Jeśli Bóg w tych samych okolicznościach może chcieć i nie chcieć, jeśli to samo może Go zadowalać i nie zadowalać" (Sade 1976: 60 [polskie wydanie Sade 2006]). W formie, która nadała nadchodzącemu utylitaryzmowi takie przekonanie, określono, że złe zamiary mogą mieć dobre skutki i odwrotnie ${ }^{49}$. To przekonanie musiało zablokować moralność braną na poważnie lub przemienić ją w nauki społeczne. Niezwykła anomalia tego paradoksu ułatwiła rozwiązanie problemu. Obydwa warianty paradoksu nie mają równej wartości. Jeśli ktoś działa kierując się godnymi potępienia zamiarami, to nie można mu przeszkodzić, jeżeli jego działania maja dobre skutki. Paradoks blokuje jedynie dobre zamiary. Te jednak, w dużej mierze wbrew Kantowi, są usprawiedliwione same z siebie. Cały paradoks zawiera osobliwą bliskość działania, tendencję do odblokowywania wynikających z paradoksu blokad. To przesunięcie - owa sekularyzacja moralności, owa zbyteczność religijnej osłony paradoksu w optymistycznej co do postępu epoce, która postęp przypisywała samej sobie - przynależy do semantyki religijno-moralnej.

Druga osobliwość moralnego paradoksu ukazała się po raz pierwszy w czasie rewolucji francuskiej. Można przyporządkować obydwa warianty paradoksu dwóm różnym systemom funkcjonalnym. Dobre skutki godnych potępienia zamiarów pojawiają się w gospodarce i uzasadniają prywatne dążenie do celu. Przeciwnie, złe skutki dobrych zamiarów sa typowe dla polityki i wymagają szczególnych środków zaradczych, przede wszystkim w konstytucji. W naturalny sposób problem, który początkowo dotyczył religii, zmienił się, przechodząc przez moralną fazę przejściową

\footnotetext{
${ }^{48}$ Por. Bellegarde (1701); Anthony, Earl of Shaftesbury (1968b). Zob. także Schwanitz (1986: 426-446).

${ }^{49}$ Jeden z najbardziej znanych przykładów: Mandeville (1924).
} 
w strukturalny problem systemów funkcjonalnych - w każdym razie doktryna liberalna pozwala nam wierzyć, że znalazł on dobre rozwiązanie.

Gdy społeczeństwo zmieniało formę swego różnicowania, szczelna, semantyczna opieka religii nad wieloma zakresami zadań społecznej komunikacji okazała się po tym wszystkim przyczyną napięć i rozdarć. Najbardziej wyodrębniony system funkcjonalny, który nie może skorzystać ze zmiany, ponieważ własną semantykę traktował jako semantykę dla całego społeczeństwa, jest tym samym najsilniej dotknięty. Przebudowa społeczeństwa stanowi podstawę dla oderwania się od religijnego ustanowienia świata, a religia wspiera ja - po części dlatego, że chce jej zapobiec i przez to wymusić doświadczenie różnicy, a po części dlatego, że pozwala sobie na prymat własnych funkcji, sugerując to samo innym systemom.

Przełożyła Kinga Marulewska Przekład przejrzał Marek M. Kurowski

/// Ausdifferenzierung der Religion, w: Gesellschaftstruktur und Semantik, tom 3, s. 283-309 (C) 1989 Suhrkamp Verlag, Frankfurt am Main 1989. Published with permission of Suhrkamp Verlag. Dziękujemy za zgodę na opublikowanie przekładu.

Bibliografia:

/// Anthony, Earl of Shaftesbury. 1968a. An Inquiry Concerning Virtue of Merit (1709). W: Tenże. Characteristics of Men, Manners, Opinions, Times, t. II. Farnborough Hants.

/// Anthony, Earl of Shaftesbury. 1968b. An Essay of the Freedom of Wit and Humour (1709). W: Tenże. Characteristics of Men, Manners, Opinions, Times, t. I. Farnborough Hants.

/// Awn, P. 1983. Satan's Tragedy and Redemption: Iblis in Sufi Psychology. Leiden: E.J. Brill.

/// Barth, F. 1975. Ritual and Knowledge among the Baktaman of New Guinea. Oslo: Universitetvorlag.

/// Bellegarde, J.B.M. de. 1701. Réflexions sur le ridicule, et sur les moyens de l'éviter. Amsterdam: Henri Schelte.

/// Black, R. 1982. Ancients and Moderns in the Renaissance: Rhetoric and History in Accolti's Dialogue on the Preeminence of Man of His Own Time. ,Journal of the History of Ideas" 43: 3-32.

/// Bonucci, A. 1906. La derogabilità del diritto naturale nella scholastica. Perugia. /// Buck, A. 1973. Die "quarelle des anciens et des modernes” im italienischen Selbstverständnis der Renaissance und des Barock. Wiesbaden: Steiner. 
/// Calasso, G. 1970. Intervento d'Iblis nella Creazione dell'uomo. „Rivista degli studi orientali" 45: 71-90.

/// Ceñal, R. 1951. Anti-Maquiavelismo de los tratadistaspoliticos de los siglos XVI y XVII. W: Castelli E. (red.). Umanesimo e scienza politica. Milano: Marzorati, s. 61-67.

/// Certeau, M. de. 1972. Du système religieux à l'éthique des Lumières (17e-18e s.). La formalité des pratiques, „Ricerche di StoriaSociale e Religiosa” 1, 2 : 31-94. /// Chenu, M.-D. 1974. Les passions vertueuses: l'antropologie de saint Thomas, „Revue philosophique Louvain” 72: 11-18.

/// Delumeau, J. 1983. Le péché et la peur: La culpabilisation en Occident (XIII -XVIII siècles). Paris: Fayard.

/// Delumeau, J. 1994. Grzech i strach: poczucie winy w kulturze Zachodu XIII -XVIII w. Przeł. Szymanowski, A. Warszawa: PAX.

/// Des Coustures, J. 1687. La Morale Universelle, Paris.

/// Duclos, Ch. 1970. Considérations sur les Mcurs de ce Siècle (1751). Lausanne: Rencontre.

/// Führer-Haimendorf, Ch. von. 1953. The After-Life in Indian Tribal Belief. "Journal of the Royal Anthropological Institute" 83: 37-49.

/// Gerhardt, V. 1976. Interesse. W: Historisches Wörterbuch der Philosophie, t. IV. Basel-Stuttgart: Schwabe Verlag.

/// Gernet, J. 1978. La vie quotidienne en Chine à la veille de l'invasion mongole 1250-1276, Paris: Hachette.

/// Gierke, O. von. 1958. Johannes Althusius und die Entwicklung naturrechtlicher Staatstheorien. Aalen: Scientia.

/// Gössmann, E. 1974. Antiqui und Moderni im Mittelalter: Eine geschichtliche Standortbestimmung. München: F. Schoning.

/// Gouge, T. 1690. The Principles of Christian Religion. London.

/// Gros, G. 1979. Le diable et son adversaire dans l'Advocacie de Nostre Dame (un poème du XIVe siècle). W: Le diable au moyen âge. Aix-en-Provence-Paris, s. 237-258.

/// Hall, Ch. 1965. The Effects of Civilization on the People in European States. New York: A.M. Kelley.

/// Hardison, O.B. 1962. The Enduring Monument: A Study of the Idea of Praise in Renaissance Literary Theory and Practice, Chapel Hill, N. C.: The University of North Carolina Press.

/// Hirschman, A.O. 1980. Leidenschaften und Interessen: Politische Begründungen des Kapitalismus vor seinem Sieg. Przeł. Offe, S. Frankfurt/Main: Suhrkamp. /// Howard, D.R. 1966. The Three Temptations: Medieval Man in Search of the World. New Jersey: Princeton University Press.

/// Jung, L. 1925. Fallen Angels in Jewish, Christian and Mohammedan Literature: A Study in Comparative Folklore. „The Jewish Quaterly Review” 15: 467-502. 
1926, 16: 45-88, 171-205, 287-336.

/// Keys, J. (Spencer Brown G.) 1971. Only Two can play This Game. Cambridge: Cat Books.

/// Le Brun,J. 1987. Das Geständnis in den Nonnenbiographien des 17. Jahrbunderts.

W: Hanh, A., Kapp, V. (red.). Selbstthematisierung und Selbstzeugnis: Bekenntnis und Geständnis. Frankfurt, s. 248-264.

/// Le diable au moyen âge (doctrine, problèmes moraux, représentations). 1979. Aix-en-Provence-Paris.

/// Le Roy, L. 1577. De la vicissitude ou variete des choses en l'univers. Paris.

/// Lehner, H. i Meran G., Möller J. 1980. De statu corruptionis: Entscheidungslogische Einübungen in die böhere Amoralität. Konstanz: Libelle -Verlag.

/// Luhmann, N. 1965. Öffentlichrechtliche Entschädigung, rechtpolitisch betrachtet. Berlin: Duncker \& Humblot Verlag.

/// Luhmann, N. 1982. Liebe als Passion: Zur Codierung von Intimität. Frankfurt/Main: Suhrkamp.

/// Luhmann, N. 1989. Die Ausdifferenqierung der Religion. W: Tenże. Gesellschaftsstruktur und Semantik, t. III. Frankfurt/Main: Suhrkamp.

/// Luhmann, N. 2003. Semantyka mitości. O kodowaniu intymności. Przek. Łoziński, J. Warszawa: Scholar.

/// Mandeville, B. 1924. The Fable of the Bees: Or Private Vices, Publick Benefits. Oxford: Clarendon Press.

/// Margiotta, G. 1953. Le originiitaliane de la querelle des anciens et des modernes. Roma: Editrice Studium.

/// Marinella, L. 1600. Le nobilità et eccelenze delle donne: et $i$ difetti, e mancamenti de gli huomini. Venetia.

/// Marquard, O. 1981. Felix culpa? - Bemerkungen zu einem Applikeationsschicksal von Genesis 3. W: Fuhrmann, M. i in. (red.). Text und Applikeation: Theologie, Jurispruden₹ und Literaturwissenschaft im hermeneutischen Gespräch. Poetik und Hermeneutik, t. IX. München: Fink, s. 53-71.

/// Mattei, R. de. 1969. Dal Premachiavellismo al Antimachiavellismo europeo del Cinquecento. Firenze: Sansoni.

/// Mesnard, P. 1953. BarbosaHomem et la conception baroque de la raison d'Etat. W: Castelli, E. (red.). Christianesimo e ragion di stato. Roma-Milano: FratelliBocca, s. 109-116.

/// Mikołaj z Kuzy. 1964a. De venatione sapientie. W: Gabriel, L. (red.) Philosophisch-theologische Schriften, t. I. Wien: Herder.

/// Mikołaj z Kuzy. 1964b. De docta ignorantia. W: Ibidem.

/// Mora, F. de la. 1949. Maquiavelo, visto por los Tratadistas politicos españoles de la Contrar-Reforma. „Arbor 13” 43-44: 417-449.

/// Nierembert S.J., Jean E. 1676. La balance du temps et de l'éternité. Le Mans. 
/// Noel, P. F. 1780-1781. Mémoire sur l'état des Missions de la Chine... (1703). W: Lettres édifiantes et curieuses, écrites des missions étrangeres, t. XVII. Paris, s. $160-183$.

/// O’Malley, J. W. 1979. Praise and Blame in Renaissance Rome: Rhetoric, Doctrine, and Reform in the Sacred Orators of the Papal Court, c. 1450-1521. Durham, N. C.: Duke University Press.

/// Ogorek, R. 1984. Das Machtspruchmysterium. „Rechtshistorisches Journal” 3: 82-107.

/// Ohly, F. 1976. Der Verfluchte und der Erwäblte: Vom Leben mit der Schuld. Opladen: Vorträge G 207 der Rheinisch-Westfälischen Akademie der Wissenschaften.

/// Payen, J.-Ch. 1967. Le motif du repentir dans la littérature française médiévale (des origines à 1230). Genf: Librairie Droz.

/// Pontano, I.I. 1556. De Fortuna. W: Tenże. Opera Omnia, t. I. Basilea.

/// Reynolds, E. 1971. A Treatise of the Passions and Faculties of the Soule of Man (1640). Gainesville, Fla.: Scholars; Facsimiles \& Reprints.

/// Rosengren W. R. i Lefton, M. (red.). Organizations and Clients: Essays in the Sociology of Service. Columbus, Ohio: Barnes \& Noble, s. 205-222.

/// Russell, J.B. 1984. Lucifer: The Devil in the Middle Ages. Ithaca, N.Y.: Cornell University Press.

/// Sade, Marquis de. 1976. Histoire de Juliette ou les prospérités du vice (1797), t. I. Paris: Union Generale d'Éditions.

/// Sade, Marquis de. 2006. Julietta - powodzenie występku. Przeł. Banasiak, B., Matuszewski, K. Kraków: Mireki.

/// Sahlins, M.D. 1968. Tribesmen. Englewood Cliffs, N.J.: Prentice-Hall. /// Scholz, F. 1987. Heil statt Verdammnis - der religiöse Code im Licht des Evangeliums: Zugleich eine Einladung zum Gespräche mit Karl Barth. W: Baekket, D. i in. (red.). Theorie als Passion. Frankfurt/Main: Suhrkamp, s. 107-136.

/// Schwanitz, D. 1986. Natürlichkeit und Lächerlichkeit: Probleme der Verbaltensstilisierung in der englischen Restaurationskomödie.

/// H. U., Pfeiffer, K. L. (red.). Stil: Geschicbten und Funktionen eines kulturwissenschaftlichen Diskurselements. Frankfurt: Suhrkamp, s. 426-446.

/// Senault, J. F. 1641. De l'usage des Passions. Paris.

/// Silhon, J. de. 1661. De la certitude des connoissances humaines. Paris: Fayard. /// Spahn, P. 1984. Die Anfänge der antiken Ökonomik. „Chiron” 14: 301-323. /// Spangenberg, P.-M. 1987. Maria ist immer und überall: Die Alltagswelten des spätmittelalterlichen Mirakels. Frankfurt: Suhrkamp.

/// Spontone, C. 1599. Dodici libri del governo di Stato. Verona: Pigozzo \& de Rossi.

/// Stödter, R. 1933. Öffentlich-rechtliche Entschädigung. Hamburg: Lütcke \& Wulff. 
/// Tuck, R. 1979. Natural Rights Theories: Their Origin and Development. Cambridge: Cambridge University Press.

/// Van Parijs, P. 1977. Distributions and Contrepied Strategies: A Contribution to a Pure Theory of Expressive Behaviour. „Journal for the Theory of Social Behaviour" 7: 129-160.

/// Villiers, P. de. 1700-1702. Pensées et reflexions sur les égaremens des hommes dans la voye du salut. Paris: Collombat.

/// Wright, T. 1971. The Passions of the Minde in Gerenall (1601). Urbana Illinois: University of Illinois Press. 